\title{
Combined Test of Jatropha Biodiesel Based on Altitude Towards Arbuscular Mycorrhizal Fungi (AMF) Combination with Cultivars and Cytokinins
}

\author{
R. Budiasih ${ }^{1, *}$, Kovertina Rakhmi Indriana ${ }^{1,2, *}$, Reni Nurhayatini ${ }^{1}$, Roni Assafaat \\ Hadi $^{1}$, Noertjahyani ${ }^{1}$, Karyana K.S. ${ }^{3}$ \\ ${ }^{1}$ Department of Agriculture, Winaya Mukti University, Jl. Raya Bandung - Sumedang Km.29 Tanjungsari 45362, Sumedang Regency, West \\ Java, Indonesia; ${ }^{2}$ Department of Agriculture, Padjadjaran University, Jl. Raya Bandung - Sumedang Km.21 Jatinangor 45363, Sumedang \\ Regency, West Java, Indonesia; ${ }^{3}$ Department of Agribusiness, Winaya Mukti University, Jl. Raya Bandung - Sumedang Km.29 Tanjungsari \\ 45362, Sumedang Regency, West Java, Indonesia
}

Received: March 9, 2021; Revised: June 17, 2021; Accepted: November 9, 2021

\begin{abstract}
The increase in Government policy from B20 to B30 towards Jatropha biodiesel tends to increase every year but the current condition is constrained by low yields both in quality and quantity, so that improvement efforts are needed to increase the yield of Jatropha biodiesel. The dosing of Arbuscular Mycorrhizal Fungi (AMF) with Jatropha cultivar and cytokinin concentrations is expected to increase the yield of Jatropha biodiesel in two different locations based on altitude, where the research was verificatived. The experiment starts from January to August 2019 at an altitude of 0-50 masl (lowland) and an altitude of 750-850 masl (medium land). The combination trial evaluated the Jatropha cultivar and the best AMF dosage and cytokinin concentrations that were repeated 3 times. The results of the experiment showed that there was an effect of the best interaction between AMF, cultivars, and cytokinin concentrations on the increased yield of fruit per plant (55.33 g), number of seeds per plant (124.17 g), fruit fresh weight per plant (208.55 g), Fresh weight of 100 seeds (70.22 g), seed fresh weight per plant (39.28 g) and biodiesel oil yield that was increased in Cirebon (42.66\% - 47.50\%) compared to Jatinangor (35.44\% $-44.10 \%)$.
\end{abstract}

Keywords : Combined test, Jatropha biodiesel, Arbuscular Mycorrhizal Fungi, Cytokinins.

\section{Introduction}

One of the government programs in 2016 is the declaration of the use of B20 (a substitute for diesel with a composition of $20 \%$ biodiesel and $80 \%$ diesel). There are 2 types of viable development opportunities for biofuels, namely biodiesel and bioethanol. Esspecifically to make biodiesel, Jatropha can be chosen because this plant does not compete with food-producing plants, it is not eaten by animals as it is toxic, environmentally friendly, easy to adapt in tropical and subtropical climates in marginal and non-marginal areas, even though the environmental conditions are not good, but showed better crop performance and productivity. This plant has the advantage of fast growth and ease of propagation (Meher, et al., 2013). Jatropha biodiesel has competitive economic value because it is an alternative energy material from fossil fuels, where the price is relatively cheaper, environmentally friendly and renewable.The availability of fertile land decreases due to the higher land use change to settlement, along with the increasing number of people. Therefore, marginal land use is one of the important solutions to do. One type of marginal soil is the order inceptisol, with limiting factors for low soil chemical fertility, especially elemental phosphate (P). Elemental P can become available to plants with the help of arbuscular mycorrhizal fungi (AMF) because AMF is able to extract phosphate from its bonds with $\mathrm{Al}^{+}, \mathrm{Fe}^{2+}, \mathrm{Ca}^{+}$, and $\mathrm{Mg}^{2+}$ by removing organic acids and phosphatase enzymes where the activity of the enzymes formed depends on the activity of the enzymes that interact with them. active microbial cells (AMF) (Nannipieri et. al., 2002). The benefits of AMF can also play a role in nutrient cycling, improve soil structure and transfer carbohydrates from plant roots to other soil organisms (Novriani and Madjid, 2010).

In some plants such as jatropha, stem tip growth often dominates the growth of other parts so that the formation of lateral branches is inhibited. This phenomenon is referred to as apical dominance. The addition of 6-benzyl aminopurine (BAP) further enhances the regeneration of leaf branches where the differential response of the genotype is influenced by cytokinins (Singh, 2017). In plants, especially jatropha, there are lateral shoots which then form lateral branches. The addition of cytokinins is one of the cultivation techniques that can be employed to enhance the growing branches aiming to obtain the maximum number of branches, so that the maximum fruit is produced. The symbiosis of arbuscular mycorrhizal fungi (CMA) with terrestrial plants is regulated by plant

\footnotetext{
*Corresponding author e-mail: entybudiasih@gmail.com ; kovertina.rakhmi.indriana@gmail.com.
} 
hormones, stimulation of cytokinins (CK) plays a role in the development of symbiosis of CMA with peanut plants; and confirm the effect of CMA inoculation on plant CK homeostasis. Most of these hormones have a role in this interrelationship; however, there are still reported contradictions for the hormone cytokinin (CK) (Dane M. Goh, et al., 2019).

The elements of climate and altitude greatly influence the plant growth process (Hasibuan., et al., 2017). The altitude of different places will vary with the physiological processes of plants. This difference will affect plant growth. Biodiesel grown in lowland areas has a higher quantity of biofuel oil than that grown in mediumland areas, but the quality of biodiesel produced is not better than that grown in midland areas, so the two locations have different oil yields, with biotic and abiotic environmental conditions that affect the ecophysiological process of plants.

\section{Materials and Methods}

The materials used in this experiment were Jatropha seed cultivar IP-3P (Improve Population 3 Pakuwon), IP3A (Improve Population 3 Asembagus), IP-3M (Improve Population 3 Muktiharjo), AMF Consortium (Glomus sp., Gigaspora sp., Acaulospora sp.) (Cucu Suherman, 2011), cytokinins (BAP), manure, chemical fertilizers used are Urea (45\% N), SP-36 (36\% P2O5), KCl (60\% K2O), and Dithane fungicide M-45. Experiments were carried out in the lowlands of Cirebon (0-50 m asl) and in the medium plains of Jatinangor (800-859 m asl), having an inceptisol soil order and rainfall types including $C$ (Schmidt and Ferguson, 1951). The trial period starts from January to June 2019.

The experimental design used was a factorial randomized block design (RBD) consisting of two factors, namely the first factor, three levels of dose combination of AMF with cultivar IP-3P : 5 g, IP- 3A : 5 g, IP-3M : $10 \mathrm{~g}$ for lowland location; IP-3P : 10 g, IP-3A : 5 g, IP-3M : 10 $\mathrm{g}$ for medium land locations and the second factor is five levels of cytokinin concentrations, namely $0 \mathrm{mg} \mathrm{L}^{-1}, 100$ $\mathrm{mg} \mathrm{L}^{-1}, 200 \mathrm{mg} \mathrm{L}^{-1}$, $300 \mathrm{mg} \mathrm{L}^{-1}, 400 \mathrm{mg} \mathrm{L}^{-1}$. The number of treatment combinations was repeated 3 times, so the number of plots in this experiment was 45 . Placement of the treatments in each replication was done randomly. Yield data (number of fruits per plant, number of seeds per plant, fresh weight of fruit per plant, fresh weight of 100 seeds, and fresh weight of seeds per plant) were calculated manually and weighed using digital scales and oil yield was obtained by the transesterification method using the Soxlet tool then all test data were analyzed statistically to determine the level of variance homogenity, by using the Bartlet test.

\section{Results and Discussion}

Before testing the combining power of the two experimental locations, it is necessary to first test the homogeneity of the variance. The level of data homogeneity between the two locations was tested using the Bartlet Test. Johnson and Winchern (2007) explain that the Bartlet test is used to test the homogeneity of the data in different populations. Test data on different populations can be analyzed in a combined manner if it has $\chi_{\text {hitung }}^{2}=-\left(n-1-\frac{1}{6}(2 p+5)\right) \ln \mid \hat{\rho}$

homogeneous data variance. The Bartlet test formula according to Sudjana (2005) is as follows:

Information $: \mathrm{n}=$ number of samples; $\mathrm{p}=$ number of variables; $\mid \dot{P}$ | = the determinant value of the correlation matrix of each variable.

Data in different populations are declared homogeneous if the count X2 is greater than X2 Table at the $5 \%$ level, it is necessary to test the combining power of the two locations (Gomez and Gomez, 1995) (Table 1). Thus, it can be concluded that the characters of the number of fruits per plant, number of seeds per plant, fresh weight of fruit per plant, fresh weight of 100 seeds, fresh weight of seeds per plant and oil yield can be tested by combined ANOVA.

Table 1. Results of the Bartlet Character Test for Character Component Results and Results

\begin{tabular}{lccccc}
\hline Character & Location & $\mathrm{db}$ & $\mathrm{X}^{2}$ Count & & $\mathrm{X}^{2}$ Table \\
\hline Number of Fruits in Plant & 2 & 1 & 40.89 & $*$ & 3.84 \\
Number of seeds in plant & 2 & 1 & 19.88 & $*$ & 3.84 \\
Fruit Fresh Weight in Plant & 2 & 1 & 8.92 & $*$ & 3.84 \\
Fresh Weight 100 Seeds & 2 & 1 & 23.09 & $*$ & 3.84 \\
Fresh Seed Weight in Plant & 2 & 1 & 27.60 & $*$ & 3.84 \\
Oil Yield & 2 & 1 & 13.94 & $*$ & 3.84 \\
\hline
\end{tabular}

Combined linear model analysis of two locations was carried out using the Freeman and Perkins analysis model as described by Singh and Chaudhary (1979) as follows :

$$
\mathrm{Y}_{\mathrm{ijkr}}=m+d_{\mathrm{i}}+e_{\mathrm{j}}+g_{\mathrm{ij}}+\varepsilon_{\mathrm{ijr}}
$$

Information : Yijr = the result of observing a variable in the ith result, the jth location, the $\mathrm{r}$ repeat; $\mathrm{m}$ = general average value; di = the effect of the first treatment; ej = effect of jth location; gij = the effect of the interaction of the i-th treatment and j-location; cijr $=$ the combined effect of other factors in the $\mathrm{i}$-th, $\mathrm{j}$-th place, and $\mathrm{r}$ th test results.

\subsection{Number of Fruits in Plants}

For the variable number of fruits per plant, the coefficient of diversity (kk) on the variable number of fruits per plant, number of seeds per plant, fresh weight of fruit per plant, fresh weight of seeds per plant ranged from $23.21 \%-29.74 \%$ while for the variable fresh weight 100 seeds ( $0.95 \%$ ) and oil yield (5.21\%). According to Gomez and Gomez (1995), a good kk value is below 20\%, although there are exceptions for quantitative characters such as outcome variables which are highly influenced by the environment (Baihaki and Wicaksana, 2005).

The number of fruits is influenced by the pollination process. Jatropha has fewer female flowers than male flowers, which will affect fruit formation. The ratio of male and female flowers is 1: 29 to 1: 13 (Pan and Zeng, 2010), so the possibility of pollination does not exist. 
Table 2. Average Number of Fruits in Plant (Fruit) of Each Treatment Planted in Different Regions Based on Altitude at Different Places

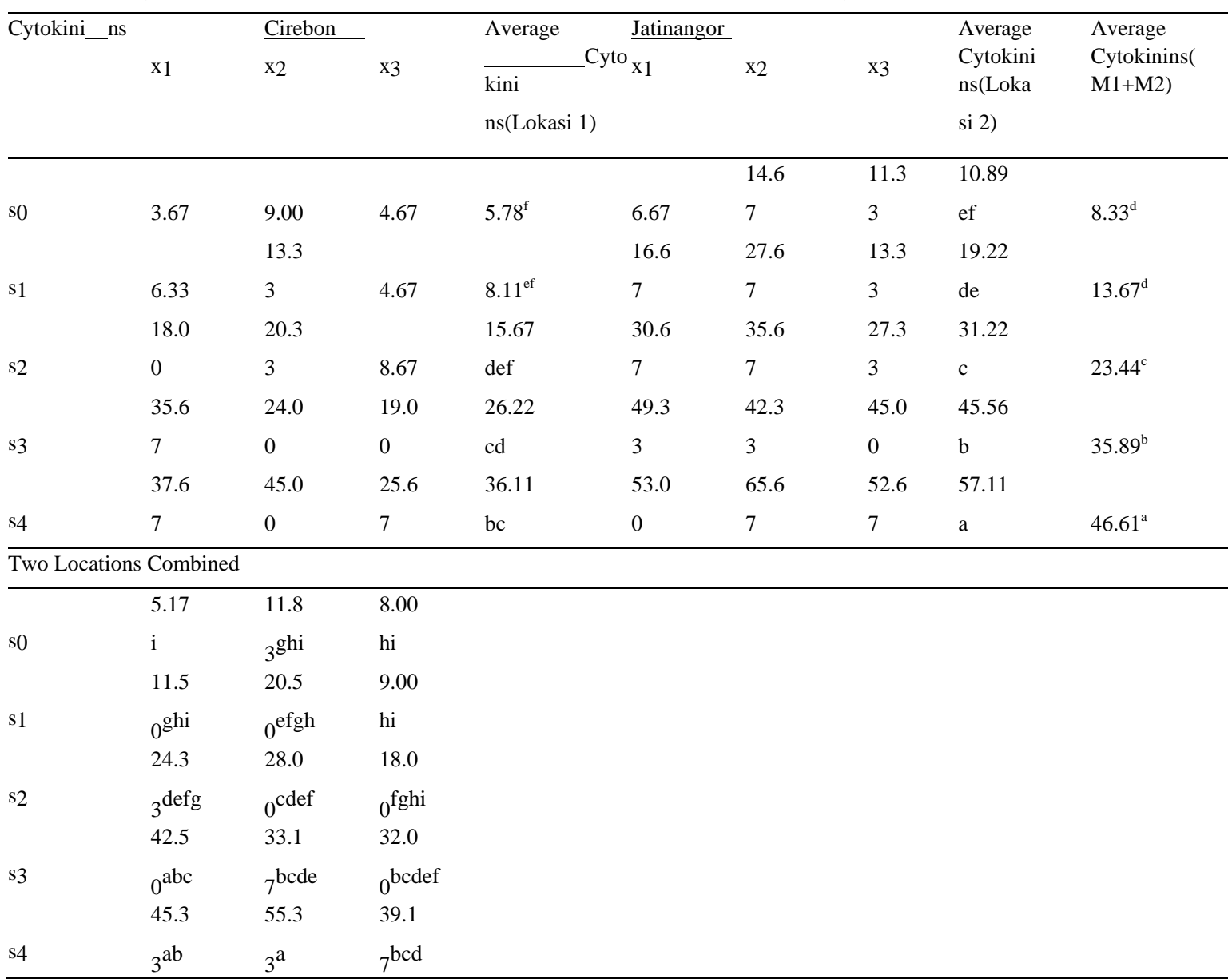

Based on the results of the combined test of the two treatment locations, the concentration of cytokinin S4 showed the best performance in the variable number of fruits per plant (46.61). The test results showed an interaction between cytokinin concentration and location. The variable appearance of the number of fruits per plant at the Jatinangor location was the highest based on the tuckey further test $(57,11)$. In addition, there was also an interaction between cytokinin concentrations and the application of Jatropha cultivar with the best AMF dose. Further test results showed that the treatment of cytokinin S4 concentration (400 mg L-1) in the Jatropha cultivar application with a dose of AMF X2 (IP-3A + dose of AMF 5 grams) had the highest average number of fruits per plant (55.33), which is also influenced by the presence of AMF which is useful for increasing nutrient uptake, especially $\mathrm{P}$ phosphate (Nur Fitriani et al., 2019).

The slow fruit formation in Jatinangor can be caused by a slower metabolic process than in Cirebon. This slow excess metabolism can increase oil yield, because less photosynthate is used for respiration. Mengel and Kirkby (2001) suggest that $80 \%$ of photosynthate is transferred to seeds in wheat plants, so it can be assumed that even in jatropha most of the photosynthate is transferred to seeds.

\subsection{Number of seeds in plant}

In the variable number of seeds per plant, the results of further tests showed that the treatment of cytokinin S4 concentration had the best performance (109.06) compared to other cytokinin hormone treatments. The test results showed that there was no interaction between cytokinin concentrations and location, although there was an interaction between cytokinin concentrations and Jatropha cultivar application with the best AMF dose. This is due to the fact that the size of the seeds is more influenced by genetic factors and there are striking environmental changes. The large flow of photosynthate from the source to the reproductive organs does not increase the capacity of the container, but is used for the process of seed growth, so that the number of seeds that reach normal size can be increased. Seeds that have been able to pass the critical limit of the seed filling period will effectively be able to reach the perfect size. The seeds that are harvested must meet the requirements of one of the agronomic characters, namely seeds that have reached normal size. 
Table 3. Average Number of Seeds in Plant (Fruit) of Each Treatment Planted in Different Regions Based on Altitude at DifferentPlaces

\begin{tabular}{|c|c|c|c|c|c|c|c|c|c|}
\hline \multirow{2}{*}{ Cytokinins } & \multicolumn{3}{|c|}{ Cirebon } & \multirow{2}{*}{$\begin{array}{c}\text { Average_Cytokinins } \\
\text { (Location1) }\end{array}$} & \multicolumn{2}{|c|}{$\underline{\text { Jatinangor }}$} & \multirow[b]{2}{*}{ x3 } & \multirow{2}{*}{$\begin{array}{c}\text { Average } \\
\text { Cytokinins } \\
\text { (Location 2) }\end{array}$} & \multirow{2}{*}{$\begin{array}{c}\text { Average } \\
\text { Cytokinins } \\
\text { (M1+M2) }\end{array}$} \\
\hline & $\mathrm{x} 1$ & $\mathrm{x} 2$ & $\mathrm{x} 3$ & & $\mathrm{x} 1$ & $\mathrm{x} 2$ & & & \\
\hline s0 & $\begin{array}{c}16.3 \\
3\end{array}$ & $\begin{array}{c}30.6 \\
7\end{array}$ & $\begin{array}{c}21.6 \\
7\end{array}$ & 22.89 & 26.33 & 40.67 & $\begin{array}{c}31.6 \\
7\end{array}$ & 32.89 & $27.89 \mathrm{~d}$ \\
\hline $\mathrm{S}_{1}$ & $\begin{array}{c}23.3 \\
3\end{array}$ & $\begin{array}{c}58.3 \\
3\end{array}$ & $\begin{array}{c}42.0 \\
0\end{array}$ & 41.22 & 34.00 & 67.67 & $\begin{array}{c}51.6 \\
7\end{array}$ & 51.11 & $46.17 \mathrm{c}$ \\
\hline s2 & $\begin{array}{c}54.3 \\
3\end{array}$ & $\begin{array}{c}59.0 \\
0\end{array}$ & $\begin{array}{c}38.0 \\
0\end{array}$ & 50.44 & 65.00 & 70.67 & $\begin{array}{c}49.6 \\
7\end{array}$ & 61.78 & $56.11 \mathrm{c}$ \\
\hline s3 & $\begin{array}{c}82.6 \\
7\end{array}$ & $\begin{array}{c}99.3 \\
3\end{array}$ & $\begin{array}{c}62.0 \\
0\end{array}$ & 81.33 & 97.33 & $\begin{array}{c}113.3 \\
3\end{array}$ & $\begin{array}{c}74.3 \\
3\end{array}$ & 95.00 & $88.17 b$ \\
\hline $\mathrm{S} 4$ & $\begin{array}{c}114 . \\
67\end{array}$ & $\begin{array}{c}103 . \\
67\end{array}$ & $\begin{array}{c}86.3 \\
3\end{array}$ & $\begin{array}{c}101.5 \\
6\end{array}$ & $\begin{array}{c}133.6 \\
7\end{array}$ & $\begin{array}{c}114.6 \\
7\end{array}$ & $\begin{array}{c}101 . \\
33\end{array}$ & $\begin{array}{c}116.5 \\
6\end{array}$ & $\begin{array}{c}109.0 \\
6^{\mathrm{a}}\end{array}$ \\
\hline \multicolumn{10}{|c|}{ Two Locations Combined } \\
\hline $\mathrm{s}_{0}$ & $21.33^{\mathrm{f}}$ & $\begin{array}{l}35.6 \\
7^{\text {def }}\end{array}$ & $\begin{array}{c}26.6 \\
7^{\mathrm{ef}}\end{array}$ & & & & & & \\
\hline $\mathrm{S}_{1}$ & $\begin{array}{c}28.67 \\
\text { def }\end{array}$ & $\begin{array}{l}63.0 \\
0^{\text {cde }}\end{array}$ & $\begin{array}{l}46.8 \\
3^{\text {def }}\end{array}$ & & & & & & \\
\hline s2 & $\begin{array}{c}59.67 \\
\text { cdef }\end{array}$ & $\begin{array}{l}64.8 \\
3^{\text {cde }}\end{array}$ & $\begin{array}{l}43.8 \\
3^{\text {def }}\end{array}$ & & & & & & \\
\hline s3 & $\begin{array}{c}90.00 \\
\text { abc }\end{array}$ & $\begin{array}{l}106 . \\
33^{a b}\end{array}$ & $\begin{array}{l}68.1 \\
7^{\text {bcd }}\end{array}$ & & & & & & \\
\hline & 124.1 & 109. & 93.8 & & & & & & \\
\hline $\mathrm{S} 4$ & $7^{\mathrm{a}}$ & $17^{\mathrm{a}}$ & $3^{\mathrm{abc}}$ & & & & & & \\
\hline
\end{tabular}

Further test results showed that the treatment of cytokinin S4 concentration with Jatropha cultivar application with the best AMF dose X1 had the highest number of seeds per plant (124.17). The interaction between cytokinins and AMF with low levels of cytokinins affects the rate of plant development so that it stimulates the growth of AMF hyphae in the roots to continue to grow (Marco cosme and Susane Wurst, 2013) which in turn increases the number of fruits. According to Bago et. al. (2003), plants that have a high rate of photosynthesis will have high food reserves and are stored in seeds in the form of fatty acids.

Fresh weight of fruit per plant, fresh weight of 100 seeds, fresh weight of seeds per plant, and oil yield on fresh fruit weight per plant there was no interaction between cytokinin concentrations and location; cytokinin concentrations and applications of Jatropha cultivar with the best AMF dose; and cytokinin concentrations, application of Jatropha cultivar with the best AMF dose and location.

Table 4. Average of fresh fruit weights in plant, fresh weight of 100 seeds, fresh weight of seeds in plant, and yield of oil for each of the treatments planted in the two regions are different based on altitude

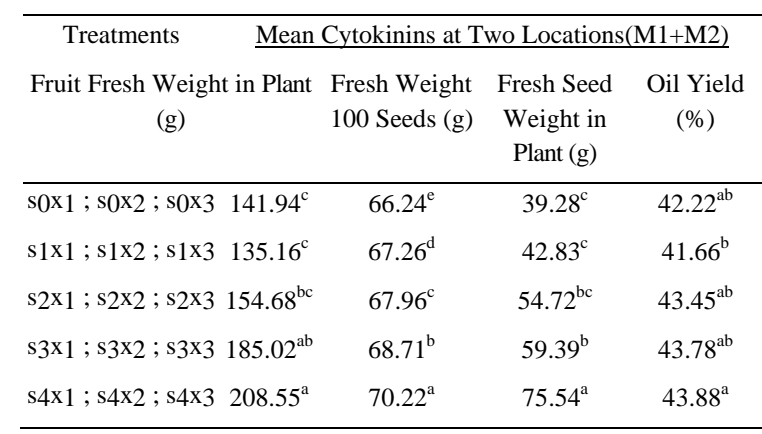

In the variable fruit fresh weight per plant, the test results showed that there was a significant difference in the application of cytokinin concentrations as a whole. The results of further tests using the tuckey test showed that the S4 application had the highest fruit fresh weight per plant reaching

208.55 grams. From Table 4, it can be concluded that the amount of photosynthate allocation in the seeds is in line with the plant biomass due to the ZPT application. High cytokinin concentrations can increase the strength of the reproductive container to attract photosynthate, so that the growth of reproductive organs is better (Sumadi, 2000).

Variable fresh fruit weight per plant (Table 4) there was no interaction between cytokinin concentrations and location; cytokinin concentrations and the application of Jatropha cultivar with the best AMF dose; as well as cytokinin concentrations, Jatropha cultivar application with the best AMF dose, and location. The test results using the tuckey test showed that there was a significant difference in the application of the overall cytokinin concentration. Further test results showed that the S4 application with the best AMF dose in each location had the highest fresh weight of 100 seeds reaching 70.22 grams. It is thought that AMF can help absorb water and nutrients, including $\mathrm{P}$ nutrient which plays an important role in seed formation. Musfal (2008) states that the increase in dry shelled yield of maize is closely related to the increase in $\mathrm{P}$ uptake byplants.

Variable seed fresh weight per plant (Table 4) did not have an interaction between cytokinin concentration and location; BAP cytokinin concentration and Jatropha cultivar application with the best AMF dose; as well as cytokinin concentrations, Jatropha cultivar application with the best AMF dose, and location. Further analysis using the tuckey test showed that there were significant differences in the application of the overall cytokinin 
concentration. The results of further tests showed that the S4 application with the best AMF dosage in each location had the highest seed fresh weight per plant, reaching 75.54 grams. According to Selamet and Suyatmo (2000), during their growth from germination to production, plants have needs that must be fulfilled such as solar radiation, $\mathrm{CO}_{2}$ for photosynthesis, $\mathrm{O}_{2}$ for respiration, water, and nutrients in certain amounts in order to grow normally to reach their potential results. The two different locations are thought to have different effects on each individual plant so that the variations that occur are quite large. Plants with mycorrhizal are more efficient in water use, then water is translocated to the top of the plant which supports the opening of the stomata, and plays a role in the process of foosynthesis which in turn will increase the production of dry matter that will be used for seed formation, so that the number of seeds formed is greater (Nuraini, 2002). The increase due to AMF administration is possible because the P- available and P from mycorrhizal secretion play a role in the preparation of phospholipids, cell nuclei and protein and increase the percentage of flower formation into fruit and seeds. $\mathrm{P}$ is also a constituent component of ATP, as an energy source for metabolic processes in plants. In plants deficient in $\mathrm{P}, \mathrm{P}$ in the cytoplasm decreases and to compensate for this so that $\mathrm{P}$ in the cytoplasm remains constant, transfer is required from the vacuole via the P-aseenzyme.

Oil yield is the ratio of the amount (quantity) of oil produced from the extraction of aromatic plants. The higher the yield value, the more oil is produced. Increasing the yield or comparison of the amount of oil produced can be done with two approaches, namely the cultivation process and the oil-

making process. From the results of the analysis showed that, treatment with additional plant AMF doses could increase the oil content significantly compared to without the addition of AMF, the more spores applied, the higher the oil content detected. The results of photosynthesis, NADPH2 and ATP can also be obtained from cellular respiration with the pentose phosphate pathway (Taiz \& Zeiger, 2006). Both of these energies are highly dependent on inorganic phosphate compounds, especially pyrophosphoric acid. Pyrophosphate is a form of inorganic phosphate molecule that can be absorbed directly by plants from the soil. According to Schacmat et al. (1998), the association between plant roots and AMF will increase pyrophosphate molecules in the soil and can increase the intensity of pyrophosphate absorption by plant 8 asetil $\mathrm{CoA}+7 \mathrm{ATP}^{3}+14 \mathrm{NADPH}+14 \mathrm{H}^{+} \longrightarrow$ palmitil $\mathrm{CoA}+7 \mathrm{CoA}+7 \mathrm{ADP}^{2-}+7 \mathrm{H} 2 \mathrm{PO}^{4-}+14 \mathrm{NADP}^{+}+7 \mathrm{H}_{2} \mathrm{O}$ roots. Thus, the more pyrophosphate compounds that plants can absorb, the more NADPH2 and ATP molecules that plants can form for fatty acid synthesis.

The basic ingredient in the formation of jatropha oil biodiesel is in the form of triglycerides which are produced from the seeds. Triglycerides are synthesized from fatty acids, glucose and glycerol. Fatty acids are derived from acetyl CoA, which occurs in the endoplasmic reticulum. Glucose is produced from photosynthesis and glycerol is produced from fructolysis. Fatty acids are important in the synthesis of triglycerides. This fatty acid formation occurs in the cytoplasm. The main basic ingredient of fatty acids is acetyl CoA which is derived from pyruvic acid in mitochondria (Salisbury and Ross, 1995). Dihydroxy acetone $\mathrm{P}$ is synthesized from glucose which occurs in the glycolysis process. Dihydroxy acetone $\mathrm{P}$ can also be obtained from the fructolysis reaction. Dihydroxy acetone $\mathrm{P}$ can be converted into $3 \mathrm{P}$ glycerol with the help of the enimglycero 13 dehydrogenase. The $3 \mathrm{P}$ glycerol will then react with fatty acids to form triglycerides. Fatty acids react with ATP and enzymes to form enzymeacyladenylate complexes. The ATP molecules in this reaction are converted into acyl-AMP and pyroP. Then acyl-AMP reacts with coenzyme A to form acetyl CoA. This acetyl CoA will react with glycero $P$ to form speech acid. Furthermore, the pidic acid is hydrolyzed to produce 1.2 diglycerides. The assimilation reaction in 1.2 diglycerides, namely the acetyl CoA molecule will bond to the $\mathrm{C}$ number 3 atom to form triglycerides. Each process of the triglyceride synthesis sequence always requires energy and enzymes involving $P$ elements, therefore giving AMF will ultimately increase the yield of castor oil seed oil. In this study it was detected that there was an increase in phosphate, presumably this element caused the oil content in the seeds of the AMF inoculated plants to increase. This study is in accordance with the study by Bago et. al. (2003), who reported that Canola plants inoculated with AMF showed a higher fatty acid content than noninoculatedplants.

The oil yield in Cirebon (42.66\% - 47.50\%) was higher than that in Jatinangor ( $35.44 \%-44.10 \%)$, because the lipid / oil formation process in Cirebon is more perfect, without being divided for respiration (Rosniawaty, 2011). Fat formation requires a lot of energy, because almost 2 pairs of electrons (2 NADPH) and one ATP are needed for each acetyl group present (Salisbury and Ross, 1995), here is a summary of fatty acid synthesis with the example of palmitic acid (as an ester of co- enzyme $\mathrm{A}$ ):

\section{Conclusion}

The results showed that there was an effect of the best AMF interaction with cultivars and cytokinin concentrations, where the best combination of AMF and cultivar and the best concentration of $400 \mathrm{mg} \mathrm{L}-1$ cytokinins was able to increase the yield of fruit number per plant (55.33 g), number of seeds per plant $(124,17 \mathrm{~g})$, fresh weight of fruit per plant (208.55 g), fresh weight of 100 seeds (70.22 g), fresh weight of seeds per plant (39.28 g) and increased yield of biodiesel oil in Cirebon (42.66\%) - $47.50 \%$ ) higher than in Jatinangor (35.44\% - 44.10\%).

\section{Acknowledgments}

LPDP (Education Fund Management Institute) which has provided an opportunity for writers to obtain a 2016 BUDI - DN doctoral education scholarship and has provided a Dissertation Research Fund; Faculty of Agriculture, Padjadjaran University (UNPAD), which has facilitated this research; and the Academic Community of Winaya Mukti University who has supported the author to continue her studies. 


\section{References}

Aneesha Singh. 2017. N-(2-chloro-4-pyridyl)-N-Phenylurea Enhanced Regeneration of Jatropha Curcas Leaf Explants by High Mineral Acquisition. J Biologia. 72 (3) : 300-304

Bago, B., Zipfel, W., Williams, R., Jun, J., and Arreola, R. 2003. Translocation and Utilization of Fungal Lipid in the Arbuskular Mycorrhizal Symbiosis. J Plant Physiol, 128:331-340.

Baihaki, A., and N. Wicaksana. 2005. Genotype x Environment Interaction, Adaptability, and Yield Stability, in the Development of Superior Varieties in Indonesia. Zuriat 16 (1):1-5.

Dane M. Goh, Marco Cosme, Anna B. Kisiala, Samantha Mulholland, Zakaria M. F. Said, Lukáš Spíchal, R. J. Neil Emery, Stéphane Declerck and Frédérique C. Guinel. 2019. A Stimulatory Role for Cytokinin in the Arbuscular Mycorrhizal Symbiosis of Pea. Frontiers in Plant Science 10 : 268.

Gomez, K. A., and A.A Gomez. 1995. Statistical Procedures for Agricultural Research. Translation : E. Sjamsuddin and J. S Baharsyah. University of Indonesia, Jakarta.

Hasibuan, S., R. Mawarni and R. Hendriadi. 2017. The Response of Giving Bagasse Bokashi Fertilizer and Water Hyacinth Bokashi Fertilizer to the Growth and Production of Soybean (Glycine max (L) Merril.). BERNAS Agr Res J (BARJ) 13 (2) : 59-64.

Johnson, R. A., and Winchern, D. W. 2007. Applied Multivariate Statistical Analysis (six edition). United State of America : Prentice.

Meher L.C., C.P. Churamania, Md. Arifb, Z. Ahmedb, and S.N. Naikc. 2013. Jatropha Curcasas a Renewable Source for Bio-Fuels. Renew Sust Energy Rev, 26 : 397-407.

Marco Cosme and Susanne Wurst. 2013. Interactions Between Arbuscular Mycorrhizal Fungi, Rhizobacteria, Soil Phosphorusand Plant Cytokinin Deficiency Change the Root Morphology, Yield and Quality of Tobacco. Soil Biol Biochem, 57 : 436-443.

Mengel, K and E. Kirkby. 2001. Principles of Plant Nutrition. International Potash Institute, Switzerland. 4-655 hal.

Musfal. 2008. Effectiveness of Arbuscular Mycorrhizal Fungi (AMF) on Location-Specific Fertilizer for Corn on Inceptisol Soil. Thesis. University of North Sumatra.79p.

Nannipieri P, Kandeler E, and Ruggiero P. 2002. Enzyme Activities and Microbiological and Biochemical processes. In : Burns RG, Dick RP (eds) Enzymes in the environment. Activity, Ecology and Applications. Marcel Dekker, New York, pp1-3.

Novriani and Madjid. 2010. Role and Prospects of Mycorrhizae. Sriwijaya University, Palembang.

http://www.scribd.com/doc/22391846/Peran-Dan-ProspekMikoriza. accessed on April 10,2017.
Nuraini, A. 2002. Response of Soybean (Glycine max (L.)Merr.) to Potassium and Arbuscular Mycorrhizal Fungi in Drought-Triggered Conditions During the Pod Forming Period to Seed Filling. Dissertation. Padjadjaran University Graduate Program. Not Published, Bandung.

Nur Fitriani Litta, Rachmawati Hasid, and Laode Afa. 2019. Effectiveness of Arbuscular Mycorrhizae and Sago Dregs in Increasing the Yield of Okra (Abelmochusesculentus L.) Plants on Dry Land. Int J Agr, 7 (1) : 23-31.

Salisbury, F.B. and C.W. Ross. 1995. Plant physiology. 3rd Editio. Wadsworth Publishing Co. Inc.

Santi Rosniawaty. 2011. Response of Jatropha carcass L. to Organic Fertilizer, Nitrogen and Phosphorus in Two Different Locations. Dissertation. Unpad Postgraduate Program, Bandung.

Schachmat, D.P., Reid, J. R., and Ayling, S.M. 1998. Phosphorus Uptake by Plants From Soil to Cell, University of Adelaide, Australia. J Plant Physiol 166 :447453.

Schmidt, F.H. and J.H.A. Ferguson. 1951. Rainfall Types Based on Wet and Dry Period Ration for Indonesia with Western New Guinea. Verhandelingen No. 42. Ministry of Transportation. Department of Meteorology and Geophysics, Djakarta.

Slamet and Suyamto. 2000. Preliminary Yield Test of Drought Tolerant Soybeans. Technique Report of Research Results, Research Institute for Legumes and Tubers.

Suherman, C. 2011. Increased Growth, Results and Oil Yield (Jatropha curcas Linn) Through the Application of Mycorrhizal Fungi and Phosphate Fertilizer in Inceptisol Jatinangor. Dissertation. Unpad Postgraduate Program, Bandung.

Sudjana. 2005. Statistical Methods. Bandung : Tarsito.

Sumadi. 2000. Responses of Soybeans That are Stricken With Drought During The Pod Forming Period to Seed Development to the Application of Cytokinins and Gibberellins. Dissertation. Unpad Postgraduate Program, Bandung.

Taiz, L., and E. Zeiger. 2006. Plant Physiology, 3rd Ed. Sinauer Associates.Sunderland.

Pan, BZ and Zeng-Fu Xu. 2010. Benzyladenin Treatment Significantly Increase the Seed Yield of the Biofuel Plant Jatropha curcass. $J$ Plant Growth Regul. DOI 10.007/S003.44-010-9179-3. www.jatropha.de/journal.(24/12/2019).

Sidiq, Yasir., Subiastuti, Aprilia Sufi., Wibowo, Wiko Arif, Daryono, and Budi Setiadi. 2020. Development of SCAR Marker Linked to Begomovirus Resistance in Melon (Cucumis melo L.). Jordan J Biol Sci, 13 (2) : 145-151.

Purnobasuki, Hery., Hariyanto, Sucipto and Purnama, and Putut Rakhmad. 2021. Genetic Diversity of Seagrass Thalassiahemprichii and Enhalusacoroides in Coastal Area of East Java. Jordan J Biol Sci. 14 (1): 111-119. 